\title{
Bireysel Hisse Senedi Yatırımcılarının Bilişsel Önyargıları Üzerine Bir Araştırma*
}

\author{
Gülşah Gizem ANGI** \\ İsmail BEKCI $* * *$ \\ Özlem Nilüfer KARATAŞ****
}

\section{ÖZET}

Hisse senedi yatırımcları yatırım kararlarını verirken birçok durumun etkisi altında kalmaktadırlar. Yatırımcıların cinsiyetleri, medeni halleri, mesleki durumları, eğitim durumları, yaşları ve gelir durumları yatırım yaparken, her yatırımcıyı farklı şekilde etkilemektedir. Ayrıca bu demografik özelliklerin yanında yatırımcıların psikolojik eğilimleri de alım-satım kararlarında önemli rol oynamaktadır. Çalışmamızda bireysel hisse senedi yatırımcılarının yatırım kararları ile, demografik özellikler ve psikolojik eğilim türlerinden biri olan bilişsel ön yargılar arasında bir ilişki olup olmadığ ve varsa bu ilişkinin düzeyi tespit edilmiştir. Bu amaçla, öncelikle çalışmada yatırımcıların bilişsel önyargıları hakkında genel bilgi verilmiştir. Akabinde Batı Akdeniz Bölgesinde (Antalya, Isparta ve Burdur) bireysel yatırmmcllara yönelik bir anket çalışması yapılmış ve elde edilen veriler Frekans analizi, aritmetik ortalama, standart sapma, iki boyutlu faktör analizi, T-testi analizi ve One-Way Anova testi test edilmiş ve sonuçlar yorumlanmıştır.

Anahtar Kelimeler: Yatırım, Yatırımcı, Hisse Senedine Yatırım, Davranışsal Finans, Psikolojik Önyargl, Bilişsel Önyargı.

Jel Sinıflandirması: G02, G11, D03

\section{A Research On Cognitive Biases To Stock Of Individual Investors}

\section{ABSTRACT}

There are many cases while individual investor's decision about investment are under the influence. Investors' sex, marital status, occupational status, educational level, ages and income level are various, therefore the difference affect for each investor in a different manner when they are investing. Also, psychological tendency of investors have an important role in trading decisions in addition to demographic characteristics. In our study, we examined whether there was the relation between individual share holds' investment decision and cognitive biases which include both to demographic characteristics and Psychological tendency or not, if there was the level of relationship was detected. For this aim, the general information about cognitive biases of investors was given. Then a survey-base study was conducted on individual investors in the West Mediterranean Region (Antalya, Isparta and Burdur) and the data was analysed with Frequency analysis, Arithmetic mean, Standart deviation, Principal component analysis, T-Test, One-Way Anova and the results had been interpreted.

Key Words: Investment, Investors, Share Investment, Behavioral Finance, Psychological Bias, Cognitive Biases.

Jel Classification: G02, G11, D03

\footnotetext{
* Bu çalışma "Bireysel Hisse Senedi Yatırımcılarının Bilişsel Önyargıları Üzerine Bir Araștırma" adlı yüksek lisans tezinden geliștirilerek hazırlanmıștır.

${ }^{* *}$ Süleyman Demirel Üniversitesi, S.B.E.

*** Nevşehir Hacı Bektaş-ı Veli Üniversitesi, İIBBF, İşletme Bölümü, Muhasebe Finansman A.B.D

**** Çankırı Karatekin Üniversitesi, İIBBF, Bankacılık Finans Bölümü, Uluslararası Sermaye Piyasaları, A.B.D
} 


\section{GİRİ̧̧}

1970’lerin sonlarında, Daniel Kahneman ve Amos Tversky tarafından yapılan pek çok çalışmada psikolojik faktörlerin yatırımcılar üzerinde etkisi olduğu ortaya konmuştur. Davranışsal finans adı altında yapılan bu çalışmalarda; insan psikolojisi de işin içine katılarak belirsizlik altında karar verme durumunda yatırımcıların rasyonel davranamadıkları, bir takım psikolojik eğilimlerin etkisi altında kaldıklarına yönelik çok güçlü kanıtlar ortaya konulmuştur (Barak, 2008: 3-4).

Yapılan araştırmalar incelendiğinde insanların yatırım kararlarında rasyonel olarak riskten kaçınmak ve portföyünü çeşitlendirmek istemekle beraber, bunu uygulamaya geçiremedikleri görülmüştür. Dolayısıyla yatırımcıların aldıkları yatırım kararları, rasyonel olmaktan ziyade sezgilere ve hislere dayalı alınmaktadır. Yatırımcıların rasyonellikten ayrıldığı bu durum, ancak önyargılar ile açıklanabilir. Bireylerde meydana gelen bu rasyonaliteden ayrılma durumu, bilişsel önyargılar olarak adlandırılmaktadır. Bilişsel önyargıların finansal kararlara etkisi ile ilgili yapılan çalışmalara bakıldığında ise Daniel Kahneman ve Amos Tversky (1979)'nin yargılar ve karar verme üzerine yaptıkları araştırmanın bulgularını yayınlayıncaya kadar herhangi bir çalışma yapılmadığı görülmekle birlikte Kahneman ve Tversky'nin bu çalışmaları finans ve psikoloji arasında bir köprü oluşturmuştur (Pompain, 2006: 10).

$\mathrm{Bu}$ çalışmanın ardından, davranışsal finans literatüründe bilişsel önyargıları tespit etmek ve açıklamak amacıyla deneysel çalışmalar yapıldığı ve yayımlandığı görülmektedir. Bu çalışmalar içerisinde en önemli olanlar Tversky ve Kahneman'ın (1971, 1973, 1974, 1981, 1992) yıllarında yaptıkları çalışmalardır. Ancak psikoloji alanında çok sayıda önyargı türü üzerinde durulmasına rağmen, bunun kesin bir çerçevesi çizilememiştir (Döm, 2003: 61).

Barber ve Odean (2001) çalışmalarında, yatırımcıların aşırı işlem yapmalarına ilişkin olarak bir aracı kurumdaki 78.000 hesap üzerinden 1991-1997 dönemini kapsayan kontrollü bir çalışma gerçekleştirmişlerdir (Barber ve Odean, 2001: 266-267).

Kysar ve Hanson (1999) yaptıkları araştırmada, bazen yanılsama olarak da adlandırılan bilişsel önyargıların, sadece eğitimsiz ve zeki olmayan insanlarda değil toplumun bütün kesimlerinde anlaşılması zor bir devamlılıkla görüldüğünü tespit etmişlerdir.

Yapılan literatür taramaları sonucunda bilişsel ön yargılar ve yatırım kararları arasındaki ilişsinin incelenmesine yönelik Dünya'da bir çok çalışma yapıldığı görülmüştür. Ancak Türkiye'de bu konuyla ilgili çalışmaların ya sadece teorik açıdan yapıldığı ya da yapılan amprik çalışmaların dar kapsamlı olduğu görülmüş̧ür. Buradan hareketle konuyla ilgili kapsamlı ve istatistiksel metotların kullanılarak sonuçların değerlendirildiği bir çalışmanın eksikliği göz önünde bulundurularak, Batı Akdeniz Bölgesindeki hisse senedi yatırımcılarının davranışları ve psikolojik yönelimleri arasındaki ilişkiyi incelemek üzere bu çalışma hazırlanmıştır. 
Yapılan çalışma ön yargı türlerinden bilişsel ön yargılar baz alınarak yapıldığı için öncelikle bilişsel ön yargıların türleri hakkında kısaca bilgi verilmesi uygun olacaktır.

\section{BİLISSSEL ÖNYARGILAR}

İnsan beyni bilgisayar gibi çalışmakta, bilgileri sık sık kısa yollar kullanarak ve duygusal filtrelerden geçirerek işlemektedir. Dolayısıyla duygular kullanılarak alınan kararlarla tamamen akıl kullanılarak alınan kararlar birbirinden farklılıklar göstermektedir (Otluoğlu, 2009: 35). Daha öncede bahsedildiği üzere bireyde meydana gelen bu rasyonaliteden ayrılma durumu bilişsel önyargılar olarak adlandırılmaktadır.

Bilişsel önyargılar şu koşulların varlığında ortaya çıkmaktadır (Edwards ve Winterfeldt, 1986: 643-644):

- Yargı sonucu ortaya çıkan cevapla, doğru cevap arasında sistematik farklılıkların var olmasi durumunda,

- $\quad$ Zihinsel bir soruya doğru cevabı belirlemede bazı resmi ilkelerden yararlanma durumunda,

- Fiziki araçların yardımı olmadan soruları cevaplarken sadece sezgilerin kullanılmasinda.

Bilişsel önyargılar; aşırı güven, sonradan anlama önyargısı, optimizm önyargısı, yükleme önyargısı, ayrılma etkisi, tutuculuk önyargısı, aşina olma önyargısı, doğrulayıcı önyargı, geri görüş önyargısı, öncelik- sonralık- sulandırma etkisi ve zaman değişkenli tercihler den oluşmaktadır. Bu ön yargılar ve sebep olduğu durumlar aşağıda kısaca açıklanmıştır (Döm, 2003: 61-87).

"Optimizm önyargısıyla" davranan yatırımcılar, kendilerini diğer insanlardan üstün görmektedir. Bu durum, kendi yeteneklerini abartmalarına ve dolayısıyla olası riskleri daha düşük görmelerine neden olmaktadır.

Yatırımcıların "Tutuculuk önyargısıyla" hareket etmeleri, kısa vadede işletmelerle ilgili önemli gelişmelere ve haberlere fazla önem vermemelerine sebep olmaktadır. Diğer bir değişle yatırımcıların önceki bilgi ve inançlarına aşırı ağırlık vermesine ve bu nedenle de yeni bilgiye daha az ilgi göstermesine neden olmaktadır.

Diğer bir bilişsel ön yarg1 türü olan "Aşina olma önyargısı" ile hareket eden yatırımcılarda; sadece bildikleri şirketlere yatırım yapmak, diğer firsatları değerlendirmemek, kendi bilgi ve deneyimlerine aşırı güvenerek portföy çeşitlendirmesi yapmamak gibi davranışlar gözlemlenmektedir. 
"Doğrulayıcı önyargının" meydana getirdiği olumsuz sonuçlar ise; bireylerin, sadece kendi hipotezlerini ve inançlarını destekleyenlere inanma eğiliminde olmalarından dolayı kendi fikirleriyle aynı olan görüşlere önem vermeleri ve diğer görüşleri önemsememeleridir.

Yatırımcıların "yükleme önyarglsıyla" hareket etmeleri, başarılı yatırımları kendi yeteneklerine, başarısız yatırımları ise kötü şansa bağlayarak kendilerine aşırı güven duymalarına ve bunun sonucunda daha spekülatif ve aktif işlemler yapmalarına, bir başka ifade ile yakalamış oldukları başarıyı kendi yeteneklerine atfetmelerine ve kendilerine aşırı güven duymalarına neden olmaktadir.

"Geri görüs önyargısına" sahip yatırımcılar, belli bir sonucu elde ettikten sonra 'ben zaten biliyordum' iddiasını gösterebilmektedir. Bu önyargı yatırımcılarda, yatırım kararlarıyla ilgili ortaya çıkabilecek zor problemleri dahi çok kolay tahmin edebilecekleri ve çözüme kavuşturabilecekleri yanılsamasını arttırarak aşırı güven duygusunu arttırmaktadır. Bu durum, yatırımcıların zaman değişkenli tercihler nedeniyle, yüksek getiriler yerine kısa vadeli getirileri tercih ettiği ve gelecekte yüksek getiriler elde etmek için, kısa vadeli beklentilerden vazgeçmede isteksiz davranabilmesine neden olmaktadır.

"Öncelik etkisiyle” hareket eden yatırımcılarda şu durumları görmek mümkündür; diğer şartlar aynı olmak üzere ilk edinilen bilgi, birey üzerinde daha etkili olmaktadır. Diğer bir ifadeyle bilginin geliş sırası, bireyin karar alma sürecinde etkili olmaktadır.

"Sonralık etkisi” ise öncelik etkisinin tam tersidir. Bu önyargı türünü, en son sunulan bilginin bazen en çok etkileyen olması olarak tanımlamak mümkündür.

Son olarak, "sulandırma etkisinin" yatırımcı da, yatırım kararı verirken nötr ya da ilişkili olmayan bilginin yargılamayı ya da düşünceyi zayıflatmasına neden olduğunu söylemek mümkündür. Diğer bir değişle yatırımla ilgili ilgisiz tüm bilgileri edinme ve kullanma isteği yatırımcının yanlış karar vermesine neden olabilmektedir.

\section{BİREYSEL HISSSE SENEDİ YATIRIMCILARININ BILISSSEL ÖNYARGILARI ÜZERINE BIIR ARAŞTIRMA}

$\mathrm{Bu}$ araştırma, Batı Akdeniz Bölgesinde bulunan hisse senedi yatırımcılarının bilişsel önyargılarının düzeyini incelemek amacıyla yapılmıştır. Bu bölümde, araştırmanın amacı, kapsamı ve sınırları, hipotezleri, yöntemi, araştırma sonucunda elde edilen bulguların değerlendirilmesi yer almaktadır.

\subsection{Araştırmanın Önemi ve Amacı}

Yatırımcı davranışı, yatırımcı psikolojisi ve piyasa psikolojisi türünden kavramlar mali piyasalarda çok konuşulmakla birlikte; ampirik anlamda üzerinde fazla durulmamış konulardır. $\mathrm{Bu}$ durumdan yola çıkarak araştırmamızın genel amacı, yatırımcıların psikolojik önyargıları 
başlığı altında hisse senedi alım satımı yaparken göstermiş olduğu bilişsel önyargıların yatırım kararlarındaki rolünü tespit etmektir.

Araştırmada, cinsiyete dayalı yatırım tercihlerinin değişimi ve yatırımcı davranışları, ilişkili testler ile (frekans analizi, aritmetik ortalama ve standart sapma) tespit edilmeye çalışılmıştır. Araştırmamızın temel amacı, yatırımcılara ait altı demografik özellik ile (cinsiyet, medeni hal, yaş, eğitim, meslek ve aylık gelirler) on bilişsel önyargının, iki boyuta indirilerek (aşırı güven ve önyargı) aralarında farklılık olup olmadığı ve aralarındaki ilişkinin tespit edilmesidir. Ayrıca araştırmada, yatırımcıların gerek demografik gerekse bazı ayırt edici özellikler açısından göstermiş olduğu eğilimlerin tespit edilmesi amaçlanmıştır. Dolayısıyla araştırma, hisse senedine yatırım yapan yatırımcıları bilinçlendirmek ve kendilerini geliştirmek adına bir yol haritası olacaktır. Türkiye'deki davranışsal finans literatürüne gerek kurumsal ve güncel bilgi, gerekse nicel ve nitel bulgular aracıllğıyla önemli katkılar sağlayacaktır. Ayrıca, bu konuda çalışan yabancı araştırmacılar ve akademisyenlerin de, Türkiye'deki yatırımcı davranışlarına ilişkin bilgi sahibi olabilmelerini sağlayacak veri tabanının oluşmasını sağlayacaktır.

\subsection{Araştırmanın Kapsamı ve Sınırları}

Araştırmanın evreni, hisse senedi piyasasında meslek grubu gözetmeksizin yatırım yapan bütün yatırımcılardan oluşmaktadır. Örneklem olarak ise, Batı Akdeniz Bölgesinden Antalya, Isparta ve Burdur illerindeki hisse senedi yatırımcıları seçilmiştir. Bu araştırma, Batı Akdeniz Bölgesinden Antalya, Isparta ve Burdur illerinden tesadüfi olarak seçilen 331 bireysel yatırımcıya yüz yüze ve internet ortamında anket uygulaması olarak yapılmıştır. Güvenilirlik analizi yapılarak geçerli olacak verilere Antalya, Isparta ve Burdur illerinde toplamda en az 250 yatırımcıya anket çalışması yapılarak varılabileceği tespit edilmiş ve toplamda 353 anket çalışmasının 22'sinin 1skarta olduğu tespit edilmiştir. Kesin verilere 222'si Antalya, 109'u ise Burdur ve Isparta illerindeki bankaların ve aracı kuruluşların seans salonlarındaki bireysel yatırımcılara uygulanan 331 anket sonucunda varılmıştır.

Anket sonuçlarının değerlendirilmesinde SPSS 20 bilgisayar paket programından faydalanılmıştır. Anket sonuçları SPSS veri tabanına girilmiş, elde edilen sonuçlar Microsoft Excel ve Word programlarına aktarılarak tablo ve grafiklerden oluşturulmuştur.

\subsection{Araştırmanın Yöntemi}

Araştırmada birincil verileri elde etmede anket yöntemi kullanılmıştır. Anket çalışması Batı Akdeniz Bölgesindeki (Antalya, Isparta ve Burdur illeri) aracı kurumlar ile bankaların menkul kıymet birimlerinde hisse senedi alım satımı yapan bireysel yatırımcılara uygulanmıştır. Anketlerdeki veriler ise daha önce araştırması yapılan literatür ve anket sorularının gözden geçirilmesiyle hazırlanmıştır. 
Hazırlanan anket, iki bölümden oluşmaktadır. Birinci bölümde, kişisel bilgilere yönelik genel sorular yer alırken; ikinci bölümde ise, bilişsel önyargıların ölçümü için sorular yer almaktadır. Anketin birinci bölümü kişisel soruların 6 tanesi demografik özelliklerle ilgiliyken geri kalan 16 tanesi yatırımcıların kişisel bilgileriyle ilgilidir. İkinci bölümde ise, belirlenen değişkenleri içeren önermelerden oluşan 5'li Likert Ölçeği formu bulunmaktadır.

Araştırma bulgularını değerlendirmede ve analiz etmede veri tipine bağlı olarak öncelikle frekans, aritmetik ortalama ve standart sapma istatistikleri kullanılmıştır. İki boyutlu faktör analizi yapılarak bilişsel önyargıların en önemli iki düzeyi bulunmuş ve bunları demografik özelliklerle karşılaştırarak aralarındaki ilişkinin var olup olmadığı araştırılmıştır. Gruplar arası karşılaştırmalarda ise T-testi analizi, değişkenler arasında ilişki aramaya yönelik olarak da OneWay ANOVA testi kullanılmıştır. Analizde anlamlılık düzeyi 0,05 olarak kabul edilmiştir.

Anketin ikinci bölüm sorularında birbirleriyle ilişkili 18 değişken bir araya getirilerek iki boyutlu faktör analizi araştırması yapılmıştır. İlk 11 soru hisse senedi yatırımcılarının hisse senedine yatırım yaparkenki önyargıları ile ilgiliyken, sonraki 7 soru aşırı güven etkisiyle ilgilidir. Bu çalışmada iki boyutlu faktör analizi yapılmasının ana nedeni, aralarında ilişki bulunduğu düşünülen çok sayıdaki bilişsel önyargıların birbirleriyle ilişkilerinin anlaşılması ve yorumlanmasını kolaylaştırmak için iki boyuta indirilmesi veya özetlenmesidir. SPSS sonuçları Tablo 1' de görüldüğü gibidir.

Tablo 1: Önyarg1 ve Aşırı Güven Etkisinin Ölçümü

\begin{tabular}{|l|c|c|}
\hline & Önyargı & Aşırı Güven \\
\hline Karar verme aşamasında geçmişte yaşamış olduğum tecrübelerimin etkisi önceliğimdir. &, 653 & \\
\hline Yatırımlarımda zarar ettığimde ihtimalleri düşnerek yavaşlarım. &, 611 & \\
\hline Güvenilir şirketlerin karlı hisseleri vardır diye düşünürüm. &, 599 & \\
\hline Sıradan şrketlerin spekülatif hisseleri vardır diye düşünürüm. &, 584 & \\
\hline Her yatııımda geçmişten daha iyi sonuçlar beklerim. &, 578 & \\
\hline Aşina olduğum hisseler hakkında objektif davranırım. &, 504 & \\
\hline $\begin{array}{l}\text { Yatıım yaptığım hisse senedinin değer kaybından etkilenmeyip en azından aldığım } \\
\text { fiyata gelmesini beklerim. }\end{array}$ &, 476 & \\
\hline $\begin{array}{l}\text { Yatırımlarımda piyasadaki haberlerden, olumlu ya da olumsuz (söylentilerden) } \\
\text { etkilenirim. }\end{array}$ &, 452 & \\
\hline Yatırım kararlarımda en son edindiğim bilgi etkili olur. &, 427 & \\
\hline $\begin{array}{l}\text { Baz almı̧ olduğum fiyatların; üzerinde seyreden hisselerim karlı, altında olan hisselerim } \\
\text { zararlı olmaktadır diye düşünürüm. }\end{array}$ &, 422 & \\
\hline Hisse senedi alım satımında ilk bilgilerim yatırım kararlarımda daha etkilidir. &, 295 & \\
\hline Kendime aşırı güvendiğim için fazla işlem yaparım. & &, 731 \\
\hline Aşırı güvenli olduğum için fazla risk alırım. & &, 730 \\
\hline Online işlemlerimde spekülatif ve zararına işlem yaparım. &, 589 \\
\hline Hisse senedi alım satımı yaparken kendi yeteneklerimi abartırım. &, 586 \\
\hline Hisse senedi alımı satımı yaparken kendi görüşlerim dışındaki bilgileri reddederim. & &, 530 \\
\hline Yatırım başarısızlıklarımı kötü şansa bağlarım. & &, 492 \\
\hline Yatırım başarılarımı kişisel yeteneklerime bağlarım. & &, 475 \\
\hline
\end{tabular}


Ankette yer alan soruların ve hipotezlerin ele alınmasında gruplaştırılan iki boyut olan önyargı ve aşırı güven eğilimlerine türdeş bir yapıyı açıklamak ya da sorgulamak üzere bir bütün oluşturup oluşturmadıklarını sorgulamak için güvenilirlik testi uygulanmıştır. Güvenilirlik katsayısı olan Cronbach alpha değeri önyargı etkisi için 0,724 iken aşırı güven etkisi için 0,703 tür. $\mathrm{Bu}$ sonuçlar anketin güvenilirliğini ortaya koymaktadır. Alpha katsayısının değerlendirilmesinde uyulan değerlendirme kriterlerine göre bulunan sonuç, ölçeğin yüksek derecede güvenilir olduğunu göstermektedir. Güvenilirlik analizine ilişkin SPSS sonuçları Tablo 2 ve 3’de görüldüğü gibidir.

Tablo: 2: Önyarg1 Etkisi için Cronbach's Alpha Değeri

\begin{tabular}{|c|c|}
\hline Cronbach's Alpha Değeri & Madde sayısı \\
\hline 0,724 & 11 \\
\hline
\end{tabular}

Tablo 3: Aşırı Güven Etkisi için Cronbach's Alpha Değeri

\begin{tabular}{|c|c|}
\hline Cronbach's Alpha Değeri & Madde sayısı \\
\hline 0,703 & 7 \\
\hline
\end{tabular}

\subsection{Araştırmanın Bulguları ve Analizi}

$\mathrm{Bu}$ bölümde araştırma bulguları analiz edilmiştir, öncelikle araştırmaya katılanların demografik özellikleri sunulmuş daha sonra anket formunda yer alan bölümlerdeki sorulara verilen cevaplar analiz edilmiştir. Analiz sonuçları ise, ankette yer alan her soruya verilen cevaplar ile detaylı bir şekilde ele alınarak aşağıdaki şekilde sunulmuştur.

\subsubsection{Anket Sonuçlarının Genel Olarak Değerlendirilmesi}

Antalya, Isparta ve Burdur illerindeki bireysel yatırımcılara ait genel bir değerlendirme yapılmıştır. Bu başlık altında anket sorularına verilen yanıtların, mutlak ve nispi dağılımları verilerek değerlendirmelerde bulunulmuştur. Ankette yer alan ilk altı soru yatırımcıların demografik özelliklerini belirlemeye yöneliktir.

Tablo 4 :Anket Katılımcılarının İkametgâhlarına Göre Dağılımı

\begin{tabular}{|c|c|c|}
\hline İl & Frekans & Yüzde \\
\hline Antalya & 222 & 67,1 \\
\hline Isparta-Burdur & 109 & 32,9 \\
\hline Toplam & 331 & 100,0 \\
\hline
\end{tabular}

Tablo 4'te görüldüğü gibi ankete katılımın \%67,1'ini Antalya ilindeki yatırımcılar oluştururken, geri kalan \%32,9'u Isparta ve Burdur ilindeki yatırımcılardır. Antalya ilimizi daha çok iş sahası ve daha fazla nüfuslu olmasından dolayı Antalya iline daha fazla anket uygulanmıştır. 
Tablo 5: Anket Katılımcılarının Cinsiyetlerine Göre Dağılımı

\begin{tabular}{|c|c|c|}
\hline Cinsiyet & Frekans & Yüzde \\
\hline Kadın & 88 & 26,6 \\
\hline Erkek & 243 & 73,4 \\
\hline Toplam & 331 & 100,0 \\
\hline
\end{tabular}

Tablo 5'de görüldüğü gibi, ankete yanıt verenlerin \%26,6's1 kadın iken, erkek yatırımcıların oranı ise \%73,4 tür. Dünya genelinde de olduğu gibi bu 3 ilde de yatırımcıların çok büyük bir kısmını erkekler oluşturmaktadır. Bu sonuç doğrultusunda finansal piyasalarda ağırlıklı olarak erkek yatırımcıların faaliyet gösterdiğini söylemek doğru olacaktır.

Tablo 6: Anket Katılımcılarının Medeni Duruma Göre Dağılımı

\begin{tabular}{|c|c|c|}
\hline Medeni Hal & Frekans & Yüzde \\
\hline Evli & 243 & 73,4 \\
\hline Bekâr & 88 & 26,6 \\
\hline Toplam & 331 & 100,0 \\
\hline
\end{tabular}

Yaptığımız araştırma doğrultusunda, Tablo 6'da yatırım yapan evli erkeklerin, bekâr erkeklere oranla daha fazla olduğu görülmektedir. Evli erkeklerin oranı \%73,4 iken bekar erkeklerin oranı $\% 26,6$ ' dir.

Tablo 7: Anket Katılımcılarının Yaș Gruplarına Göre Dağılımı

\begin{tabular}{|c|c|c|}
\hline Yaș & Frekans & Yüzde \\
\hline $\mathbf{1 8 - 2 0}$ & 11 & 3,3 \\
\hline $\mathbf{2 1 - 3 0}$ & 77 & 23,3 \\
\hline $\mathbf{3 1 - 4 0}$ & 113 & 34,1 \\
\hline $\mathbf{4 1 - 5 0}$ & 78 & 23,6 \\
\hline $\mathbf{5 1 -}$ & 52 & 15,7 \\
\hline Toplam & 331 & 100,0 \\
\hline
\end{tabular}

Tablo 7'de yatırım yapma yaşının \%81'inin 21-50 yaşlar arası toplandığı görülmektedir, yalnız özellikle 40 yaşından sonra yatırım yapma oranı düşüş göstermektedir. 51 yaşından sonra yatırım yapma oranı $\% 52$ ye düşmüştür. Ayrıca 18-20 yaş arası yatırım yapma oranı ise $\% 11$ dir.

Tablo 8: Anket Katılımcılarının Eğitim Düzeyine Göre Dağılımı

\begin{tabular}{|c|c|c|}
\hline Eüitim Durumu & Frekans & Yüzde \\
\hline İlkokul & 6 & 1,8 \\
\hline Ortaokul & 10 & 3,0 \\
\hline Lise & 52 & 15,7 \\
\hline Üniversite & 205 & 61,9 \\
\hline Yüksek Lisans/Doktora & 58 & 17,5 \\
\hline Toplam & 331 & 100,0 \\
\hline
\end{tabular}

Tablo 8'de yatırımcıların yatırım yüzdesi eğitim düzeyiyle yüksek lisans/doktora yapan kişilere kadar doğru orantılı olarak artmaktadır. Ancak yüksek lisans/doktora eğitimiyle ciddi oranda düşüş yaşandığı gözlenmektedir. Bu oran üniversite eğitimi alan yatırımcılarda \%61,9 iken yüksek lisans/doktora eğitiminde $\% 17,5$ olarak gözükmektedir. İlkokul, ortaokul ve lise mezunlarının toplam oranı ise $\% 20,5(\% 1,8+\% 3+\% 15,7)$ dir. 
Tablo 9: Anket Katılımcılarının Meslek Gruplarına Göre Dağılımı

\begin{tabular}{|c|c|c|}
\hline Meslek & Frekans & Yüzde \\
\hline Öğrenci & 21 & 6,3 \\
\hline Ekonomist & 26 & 7,9 \\
\hline Akademisyen & 49 & 14,5 \\
\hline Memur & 75 & 22,7 \\
\hline İşci & 35 & 10,6 \\
\hline Diğer & 125 & 37,8 \\
\hline Toplam & 331 & 100,0 \\
\hline
\end{tabular}

Tablo 9'da ankete katılan yatırımcıların çoğunluğunun toplamını \%37,5 memurlar ve akademisyenler oluşturmaktadır. Ardından \%10,6 ile işçiler ve en düşük oy toplam 14,2 ile öğrenci ve ekonomistler oluşturmaktadır.

Tablo 10: Anket Katılımcılarının Aylık Gelir Durumlarına Göre Dağılımı

\begin{tabular}{|c|c|c|}
\hline Aylık Gelir & Frekans & Yüzde \\
\hline $\mathbf{2 . 5 0 0 ~ d e n ~ a z ~}$ & 141 & 42,6 \\
\hline $\mathbf{2 . 5 0 1 - 5 . 0 0 0}$ & 136 & 41,1 \\
\hline $\mathbf{5 . 0 0 1 - 7 . 5 0 0}$ & 33 & 10,0 \\
\hline $\mathbf{7 . 5 0 1 - 1 0 . 0 0 0}$ & 11 & 3,3 \\
\hline $\mathbf{1 0 . 0 0 1 - 1 2 . 5 0 0}$ & 2 &, 6 \\
\hline $\mathbf{1 2 . 5 0 1 - 1 5 . 0 0 0}$ & 1 &, 3 \\
\hline $\mathbf{1 5 . 0 0 1 - 1 7 . 5 0 0}$ & 1 &, 3 \\
\hline $\mathbf{1 7 . 5 0 1 - 2 0 . 0 0 0}$ & 1 &, 3 \\
\hline $\mathbf{2 0 . 0 0 1}$ ve üzeri & 5 & 1,5 \\
\hline Toplam & 331 & 100,0 \\
\hline
\end{tabular}

Tablo 10'da ankete en yüksek katılımı sağlayan aylık kazanc1 2.500-TL'den az olan yatırımcıların oranı \% 42,6 iken kazancı 2.500-TL ile 5.000-TL'ye kadar olan yatırımcıların sayısı \% 41,1'dir. Katılımcıların genel çoğunluğu aylık kazancı 5.000-TL'ye kadar olan yatırımcılardan oluşmaktadır. Geri kalan yatırımcıların \% 16,3 ünün ise aylık kazancı 5.000TL'den yüksektir. Burada dikkati çeken ise maaşı 2.500-TL'den az olan yatırımcıların çoğunlukta olmasıdır. Bunun genel nedeni ankete katılan yatırımcıların genelinin memur ve akademisyenlerden oluşmasıdır. Memur maaşlarının aylık ortalama bu fiyat aralığında olduğu bilinmektedir. Çalışmamız çerçevesinde hipotezlerde daha sağlıklı sonuçlara erişilebilmesi için aylık kazanc1 7.500-TL ve üzeri olan gelirler birleştirilmiştir.

Tablo 11: Hisse Senedi Piyasasında Faaliyette Bulunma Süresi

\begin{tabular}{|c|c|c|}
\hline & Frekans & Yüzde \\
\hline $\mathbf{1}$ yıldan az & 78 & 23,6 \\
\hline $\mathbf{1 - 2}$ yıl arası & 58 & 17,5 \\
\hline 3-4 yıl arası & 49 & 14,8 \\
\hline 4 yıldan fazla & 146 & 44,1 \\
\hline Toplam & 331 & 100,0 \\
\hline
\end{tabular}

Tablo 11'de ankete katılan yatırımcıların \% 44,1 inin hisse senedi piyasasına girişi dört yılın üzerindedir. $\mathrm{Bu}$ anlamda yatırımcıların yaklaşık yarısının hisse senedi piyasasına girişinin 
eski olduğu anlaşılmaktadır. Bir yıldan az piyasaya yeni girişlerin oranı ise \% 23,6'dır. 1 ile 4 y1l arası hisse senedine yatırım yapma oranı ise \% 32.3 tür. Genel olarak piyasalarda, ekonominin iyi olduğu ve borsa piyasasının yükselişte olduğu durumlarda hisse senedi yatırımcılarının arttığı gözlemlenmektedir.

Tablo 12: Portföyde Bulunan Şirket Sayısı

\begin{tabular}{|c|c|c|}
\hline & Frekans & Yüzde \\
\hline $\mathbf{1 - 3}$ & 182 & 55,0 \\
\hline $\mathbf{4 - 6}$ & 98 & 29,6 \\
\hline $\mathbf{7 - 9}$ & 24 & 7,3 \\
\hline $\mathbf{1 0 - 1 2}$ & 18 & 5,4 \\
\hline 13 ve üstü & 9 & 2,7 \\
\hline Toplam & 331 & 100,0 \\
\hline
\end{tabular}

Tablo 12'de yatırımcıların elinde bulundurduğu hisse senedi sayısı dağılımı verilmektedir. Yatırımcıların \% 84'lük gibi büyük bir kısmının elinde bulundurduğu hisse senedi adedi 6'nın altındadır. Küçük yatırımcı olarak da nitelendirilen bireysel yatırımcıların elindeki hisse senedi sayısı 10'u geçen yatırımcı oranı ise sadece \% 8,1'dir. Buradan yatırımcıların hisse senetlerinde genellikle sınırlı sayıda çeşitliliği benimsediklerini anlayabiliriz.

Tablo 13: Hisse Senetlerini Ortalama Elde Tutma Süresi

\begin{tabular}{|c|c|c|}
\hline & Frekans & Yüzde \\
\hline 1 haftadan az & 45 & 13,6 \\
\hline $\mathbf{2 - 4}$ hafta & 99 & 29,9 \\
\hline $\mathbf{2 - 3}$ ay & 73 & 22,1 \\
\hline $\mathbf{4 - 6}$ ay & 25 & 7,6 \\
\hline 6 aydan fazla & 89 & 26,9 \\
\hline Toplam & 331 & 100,0 \\
\hline
\end{tabular}

Tablo 13’de görüldüğü gibi bireysel yatırımcıların \% 43,5 inin hisse senetlerini ortalama elde tutma süresi bir ayın altındadır. Bu tablodan da anlaşıldığı gibi, normalde uzun vadeli bir yatırım aracı olması gereken hisse senetlerini bireysel yatırımcıların kısa sürede elden çıkarma eğiliminde olduğu görülmektedir. Bunun sonucunda yatırımcıların borsayı kısa vadeli kazanç yeri olarak gördüğünü söyleyebiliriz. Sürekli al sat yapan yatırımcıların çok sık ve zararına işlem yaptıklarını söylemek doğru olacaktır. Tablodan da görüldüğü gibi yatırımcıların sadece \% 26,9'u yatırımlarını altı aydan daha fazla bir süre devam ettirmektedir.

Tablo 14: Hisse Senetlerine Yatırım Yaparken Profesyonellerden Bilgi Alma Sıklığ1

\begin{tabular}{|c|c|c|}
\hline & Frekans & Yüzde \\
\hline Her zaman & 81 & 24,5 \\
\hline Genellikle & 85 & 25,7 \\
\hline Bazen & 86 & 26,0 \\
\hline Zaman Zaman & 45 & 13,6 \\
\hline Asla & 34 & 10,3 \\
\hline Toplam & 331 & 100,0 \\
\hline
\end{tabular}


Tablo 14'de yatırımcıların aracı kurumların ve profesyonel kuruluşların yönlendirme hizmetlerinden ne ölçüde yararlandığı gösterilmektedir. Ankete yanıt verenlerin \%24,5'i her zaman, \%25,7'si genellikle yönlendirildiğini belirtmiştir. Yani, aracı kurumlar tarafindan yoğun olarak yönlendirilen yatırımcı oranı \%50,2dir. Yatırımcıların \%10,3 lük bir kısmının ise aracı kurumlar tarafından yönlendirme hizmeti almadığı anlaşılmaktadır. Yatırımcıların \%26'sının bazen ve \%13,6'sının ise zaman zaman bu hizmetlerden yararlandığı görülmüştür.

Tablo 15: Kendinizi Nasıl Bir Yatırımcı Olarak Görüyorsunuz?

\begin{tabular}{|c|c|c|}
\hline & Frekans & Yüzde \\
\hline Çok iyi & 17 & 5,1 \\
\hline İyi & 80 & 24,2 \\
\hline Orta & 149 & 45,0 \\
\hline İyi Değil & 56 & 16,9 \\
\hline Hiç iyi değil & 29 & 8,8 \\
\hline Toplam & 331 & 100,0 \\
\hline
\end{tabular}

Tablo 15’de görüldüğü gibi yatırımcıların \% 29.3'lük küçük bir kısmı kendini aşırı güvenen iyi bir yatırımcı olarak görürken $\% 45$ 'lik büyük bir kısmı orta derece, \% 25,7'lik bir kısmı ise kendine hiç güvenmeyen kötü bir yatırımcı olarak görmektedir. Bunun sonucunda yatırımcıların elde ettiği başarılar doğrultusunda kendine güvendikleri ve kendilerini iyi bir yatırımcı olarak gördüğü, elde ettiği başarısızlıklar doğrultusunda ise kendilerini başarısız birer yatırımcı olarak gördügü söylenebilir.

Tablo 16: Hisse Senetlerinin Geçmiş Performanslarının Hisse Senedi Alım Satım Kararındaki Rolü

\begin{tabular}{|c|c|c|}
\hline & Frekans & Yüzde \\
\hline Çok önemli & 64 & 19,3 \\
\hline Önemli & 163 & 49,2 \\
\hline Orta & 65 & 19,6 \\
\hline Çok az & 26 & 7,9 \\
\hline Hiç önemli değil & 13 & 3,9 \\
\hline Toplam & 331 & 100,0 \\
\hline
\end{tabular}

Tablo 16'da yatırımcılara hisselerin geçmiş başarılarının hisse senedi alım satımı yaparken önemi sorulurken \% 68,5'i önemli olduğunu, \%11,8'i ise önemsiz olduğunu düşünmektedir. $\mathrm{Bu}$ sonuçlardan yola çıkarak kendilerini riske atmak istemeyen daha çok güvenilir hisse senedi alım satımı yapmak isteyen yatırımcıların hisselerin geçmiş performanslarını gözden geçirmesidir.

\subsubsection{Demografik Özellikler ile Önyargı Düzeylerinin Değerlendirilmesi}

$\mathrm{Bu}$ bölümde, bireysel yatırımcıların demografik özellikleri ile önyargı düzeylerinin aralarında farklılık gösterip göstermediği araştırılmaktadır. Bu doğrultuda yapılan iki yönlü faktör analizi ile yatırımcıların hisse senedi alırken göstermiş olduğu eğilimler, önyargı ve aşırı güven adı altında iki başlık altında değerlendirilmiştir. İlk olarak demografik özellikler ile 
önyargı düzeylerinin sırasıyla hipotezleri kurulmuş ve aşağıdaki gibi değerlendirilmiştir. Hipotezleri test etmek amacıyla 'Bağımsız Örneklem T-Testi ve Tek Yönlü Anova testi' kullanılmış olup güven aralığı 0,05 alınmıştır.

Problem Cümlesi: Cinsiyete göre Hisse senedi yatırımcılarının ön yargı düzeyleri anlamı farklıık göstermekte midir?

H0: Cinsiyete göre hisse senedi yatırımcılarının ön yargı düzeyleri anlamlı farklılık göstermemektedir.

H1: Cinsiyete göre hisse senedi yatırımcılarının ön yargı düzeyleri anlamlı farklılık göstermektedir.

Tablo 17: Yatırımcıların Önyargı Düzeylerinin Cinsiyeti Göre T-Testi Sonuçları $\quad(\mathrm{p}>0,05)$

\begin{tabular}{|c|c|c|c|c|c|c|}
\hline Cinsiyet & N & Ortalama & SS & Sd & t & P \\
\hline Kadın & 88 & 3,461 &, 528 & 329 &, 729 &, 466 \\
\hline Erkek & 243 & 3,411 &, 553 & & & \\
\hline
\end{tabular}

Tablo 17 incelendiğinde yatırımcıların cinsiyetleri ile önyargıları arasında anlamlı bir farklılık olmadığ 1 (t $(329)=0,729, \mathrm{p}>0,05)$ tespit edilmiştir. Bu nedenle H0 hipotezi kabul edilmektedir. Bu çalışmada elde edilen sonucun aksine Döm’ ün (2003), yaptığı araştırmada cinsiyet ile önyargı arasında farklılık olduğu ve erkeklerin kadınlara oranla hisse senetleri alım satımında daha fazla önyargılı olduğu tespit edilmiştir. Buradan hareketle bu sorunun cevabının ülkeye göre ve ankete katılanların çoğunluğunun erkek ya da kadın olmasına göre değişiklik gösterebileceğini söylemek mümkündür.

Problem Cümlesi: Medeni hale göre hisse senedi yatırımcılarının önyargı düzeyleri anlamlı farklıık göstermekte midir?

H0: Medeni hale göre hisse senedi yatırımcılarının önyargı düzeyleri anlamlı farklılık göstermemektedir.

H1: Medeni hale göre hisse senedi yatırımcılarının önyargı düzeyleri anlamlı farklılık göstermektedir.

Tablo 18: Yatırımcıların Önyargı Düzeylerinin Medeni Duruma Göre T-Testi Sonuçları (p>0,05)

\begin{tabular}{|c|c|c|c|c|c|c|}
\hline Medeni Hali & $\mathbf{N}$ & Ortalama & SS & Sd & T & p \\
\hline Evli & 243 & 3,438 &, 0336 & 329 &, 761 &, 447 \\
\hline Bekar & 88 & 3,386 &, 0607 & & & \\
\hline
\end{tabular}

Tablo 18'de yatırımcıların önyargıları medeni hale göre farklılık göstermekte midir hipotezini değerlendirmek üzere yaptığımız $t$ testi sonucunda $p>005(p=0,447)$ anlamlı bir farkl11ık göstermemektedir. Bu nedenle $\mathrm{H} 0$ hipotezi kabul edilmektedir.

Problem Cümlesi: Yaş Gruplarına göre hisse senedi yatırımcılarının önyargı düzeyleri arasında anlamlı bir farklıık var mıdır? 
H0: Yaş Gruplarına göre hisse senedi yatırımcılarının önyargı düzeyleri arasında anlamlı bir farklılık yoktur.

H1: Yaş Gruplarına göre hisse senedi yatırımcılarının önyargı düzeyleri arasında anlamlı bir farkl11ık vardır.

Tablo 19: Yaş Gruplarının Betimsel İstatistiği

\begin{tabular}{|c|c|c|c|}
\hline Yas Grubu & N & Ortalama & SS \\
\hline $18-20$ & 11 & 3,0083 &, 520 \\
\hline $21-30$ & 77 & 3,3436 &, 649 \\
\hline $31-40$ & 113 & 3,4851 &, 471 \\
\hline $41-50$ & 78 & 3,4394 &, 495 \\
\hline 51 -yukarı1 & 52 & 3,4773 &, 579 \\
\hline
\end{tabular}

Tablo 19'da Hisse senedi yatırımcılarının yaş gruplarına göre ön yargı düzeylerine ilişkin ortalama ve standart sapmaları verilmiştir. En yüksek ortalamaya sahip iki yaş gurubu 31-40 ile 51 ve yukarı yaş grubu arasındadır. Bu ortalama değerler arasında manidar bir fark olup olmadığı tek yönlü varyans analizi ile sınanmış ve aşağıdaki bulgulara ulaşılmıştır.

Tablo 20: Yatırımcıların Önyargı Düzeylerinin Yaş Gruplarına Göre Anova Testi Sonuçları $(\mathrm{P}<0,05)$

\begin{tabular}{|c|c|c|c|c|c|c|}
\hline & $\begin{array}{c}\text { Kareler } \\
\text { toplamı }\end{array}$ & sd & $\begin{array}{c}\text { Kareler } \\
\text { ortalamas }\end{array}$ & F & P & Anlamlı Fark \\
\hline Gruplar arası & 2,987 & 4 &, 747 & 2,550 &, 039 & \\
\hline Gruplar içi & 95,487 & 326 &, 293 & & & \\
\hline Toplam & 98,475 & 330 & & & & \\
\hline
\end{tabular}

Tablo 20'de hisse senedi yatırımcılarının yaş gruplarına göre önyargı düzeylerinin arasında anlamlı bir farklılık olduğu $(\mathrm{F}=2,550 ; \mathrm{p}<0,05)$ tespit edilmiştir. Bu nedenle H0 hipotezi reddedilmektedir. Buna göre, genelde orta yaşlı deneyimli yatırımcıların; önceki bilgi ve inançlarına aşırı ağılık verdiği yeni bilgiye daha az ilgi gösterdiği, ilk yaptıkları yatırımın sonucuna göre tekrardan aynı hisse senedine yatırım yapmaya meyilli oldukları, aşina olduğu hisse senetlerine karşı daha fazla meyilli oldukları ve kısa vadeli düşük getirileri uzun vadeli yüksek getirilere tercih ettikleri tespit edilmiştir. Sezer'in (2013) yapmış olduğu araştırmada ise, yatırımcıların yaş grupları ile bazı önyargılar arasında anlamlı farklılık tespit edilirken bazı durumlarda bu farkl11ı̆̆a rastlanmamıştır.

\section{Problem Cümlesi: Eğitim durumlarına göre hisse senedi yatırımcılarının önyargı düzeyleri arasında anlamlı bir farklıık var mıdır?}

H0: Ĕ̆itim durumlarına göre hisse senedi yatırımcılarının önyargı düzeyleri arasında anlamlı bir farklılık vardır.

H1: Eğitim durumlarına göre hisse senedi yatırımcılarının önyargı düzeyleri arasında anlamlı bir farklılık yoktur. 
Tablo 21: Eğitim Durumlarının Betimsel İstatistiği

\begin{tabular}{|c|c|c|c|}
\hline Eğitim Durumu & N & Ortalama & SS \\
\hline İkokul & 6 & 3,5000 &, 314 \\
\hline Ortaokul & 10 & 3,4182 &, 668 \\
\hline Lise & 52 & 3,4003 &, 550 \\
\hline Üniversite & 205 & 3,3973 &, 547 \\
\hline Yüksek Lisans/Doktora & 58 & 3,4243 &, 540 \\
\hline
\end{tabular}

Tablo 21'de Hisse senedi yatırımcılarının eğitim durumlarına göre ön yargı düzeylerine ilişkin ortalama ve standart sapmaları verilmiştir. En yüksek ortalamaya sahip eğitim durumu ilkokul ve yüksek lisans/doktora grubudur. Bu ortalama değerler arasında manidar bir fark olup olmadığı tek yönlü varyans analizi ile sınanmış ve aşağıdaki bulgulara ulaşılmıştır.

Tablo 22: Yatırımcıların Önyargı Düzeylerinin Eğitim Durumlarına Göre Anova Sonuçları $(\mathrm{P}>0,05)$

\begin{tabular}{|c|c|c|c|c|c|c|}
\hline & $\begin{array}{c}\text { Kareler } \\
\text { Toplamı }\end{array}$ & sd & $\begin{array}{c}\text { Kareler } \\
\text { Ortalaması }\end{array}$ & F & P & Anlamlı Fark \\
\hline Gruplar aras1 &, 918 & 4 &, 229 &, 767 &, 548 & - \\
\hline Gruplar içi & 97,557 & 326 &, 299 & & & \\
\hline Toplam & 98,475 & 330 & & & & \\
\hline
\end{tabular}

Tablo 22'de hisse senedi yatırımcılarının eğitim durumlarına göre önyargı düzeylerinin arasında anlamlı bir farklılık $(\mathrm{F}=, 767 ; \mathrm{p}>0,05)$ bulunmamaktadır. Bu nedenle H0 hipotezi kabul edilmektedir.

Problem Cümlesi: Meslek gruplarına göre hisse senedi yatırımcılarının önyargı düzeyleri arasında anlamlı bir farklılık var mıdır?

H0: Meslek gruplarına göre hisse senedi yatırımcılarının önyargı düzeyleri arasında anlamlı bir farklılık yoktur.

H1: Meslek gruplarına göre hisse senedi yatırımcılarının önyargı düzeyleri arasında anlamlı bir farklılık vardır.

Tablo 23: Meslek Gruplarının Betimsel İstatistiği

\begin{tabular}{|c|c|c|c|}
\hline Meslek & N & Ortalama & SS \\
\hline Öğrenci & 21 & 3,0952 &, 653 \\
\hline Ekonomist & 26 & 3,3811 &, 341 \\
\hline Akademisyen & 49 & 3,5603 &, 523 \\
\hline Memur & 75 & 3,5430 &, 474 \\
\hline İşçi & 35 & 3,3351 &, 568 \\
\hline Diğer & 125 & 3,3891 &, 579 \\
\hline
\end{tabular}

Tablo 23'de Hisse senedi yatırımcılarının meslek gruplarına göre ön yarg1 düzeylerine ilişkin ortalama ve standart sapmaları verilmiştir. Bu tabloya göre, en yüksek ortalamaya sahip iki meslek gurubu akademisyen ve memurdur. Bu ortalama değerler arasında manidar bir fark olup olmadığı tek yönlü varyans analizi ile sınanmış ve aşağıdaki bulgulara ulaşılmıştır. 
Tablo 24: Yatırımcıların Önyargı Düzeylerinin Meslek Gruplarına Göre Anova Sonuçları

\begin{tabular}{|c|c|c|c|c|c|c|}
\hline & Kareler Toplamı & sd & Kareler Ortalaması & F & P & Anlamlı Fark \\
\hline Gruplar aras1 & 4,720 & 5 &, 944 & 3,272 &, 047 & \\
\hline Gruplar içi & 93,755 & 325 &, 288 & & & \\
\hline Toplam & 98,475 & 330 & & & & \\
\hline
\end{tabular}

Tablo 24'de hisse senedi yatırımcılarının meslek gruplarına göre önyargı düzeylerinin arasında anlamlı bir farklılık olduğu $(F=3,272 ; p<0,05)$ tespit edilmiştir. Daha önce yapılmış çalışmalar incelendiğinde genellikle cinsiyet, medeni durum, yaş grubu ve aylık gelirler ile yatırımcı önyargısı arasında bir karşılaştırma yapıldığı ancak yatırımcıların meslek gruplarına göre bir bulgu elde edilmediği tespit edilmiştir. Yapmış olduğumuz çalışmada çıkan sonuçla H0 hipotezi reddedilmiş ve yatırımcı önyargısı ile meslek grupları arasında bir farklılık olduğu tespit edilmiştir. Buna göre, meslek gruplarından en fazla önyargının akademisyen ve memurlarda olduğu sonucuna varılmıştır.

Problem Cümlesi: Aylık Gelire göre hisse senedi yatırımcılarının önyargı düzeyleri arasında anlamlı bir farklılık var mıdır?

Ho: Aylık Gelire göre hisse senedi yatırımcılarının önyargı düzeyleri arasında anlamlı bir farkl111k yoktur.

H1: Aylık Gelire göre hisse senedi yatırımcılarının önyargı düzeyleri arasında anlamlı bir farklılık vardır.

Tablo 25: Aylık Gelirlerin Betimsel İstatistiği

\begin{tabular}{|c|c|c|c|}
\hline Aylık Gelir (TL) & N & Ortalama & SS \\
\hline 2.500 den az & 141 & 3,3939 &, 604 \\
\hline $2.501-5.000$ & 136 & 3,4706 &, 477 \\
\hline $5.001-7.500$ & 33 & 3,4105 &, 572 \\
\hline 7.501 ve üzeri & 21 & 3,3506 &, 529 \\
\hline
\end{tabular}

Tablo 25'de Hisse senedi yatırımlarının aylık gelirlerine göre ön yargı düzeylerine ilişkin ortalama ve standart sapmaları verilmiştir. Bu tabloya göre, hisse senedi yatırımcılarının önyargılarının ortalaması 2.500-TL'den az aylık geliri olanlar ortalama 3,3939, 2.501-5.000-TL arasında olanlar için ortalama 3,4706, 5.001-7.500-TL olanlar için ortalama 3,4105 ve 7.501-TL ve üzeri için ortalama 3,3506 düzeyindedir. En yüksek ortalamaya sahip aylık gelir ise 2.501 ile 5.000-TL arasındadır. Bu ortalama değerler arasında manidar bir fark olup olmadığı tek yönlü varyans analizi ile sınanmış ve aşağıdaki bulgulara ulaşılmıştır.

Tablo 26: Yatırımcıların Önyargı Düzeylerinin Aylık Gelir Durumlarına Göre Anova Sonuçları $(\mathrm{P}>, 05)$

\begin{tabular}{|c|c|c|c|c|c|c|}
\hline & $\begin{array}{c}\text { Kareler } \\
\text { toplamı }\end{array}$ & Sd & $\begin{array}{c}\text { Kareler } \\
\text { ortalaması }\end{array}$ & F & P & Anlamlı Fark \\
\hline Gruplar arası &, 542 & 3 &, 181 &, 603 &, 614 & - \\
\hline Gruplar içi & 97,933 & 327 &, 299 & & & \\
\hline Toplam & 98,475 & 330 & & & & \\
\hline
\end{tabular}


Tablo 26'de hisse senedi yatırımcılarının aylık gelirlerine göre önyargı düzeylerinin arasında anlamlı bir farklılık $(\mathrm{F}=, 603 ; \mathrm{p}>0,05)$ bulunmamaktadır. Bu nedenle, H0 hipotezi kabul edilmektedir.

\subsubsection{Demografik Özellikler İle Așırı Güven Düzeylerinin Değerlendirilmesi}

Demografik özellikler ile aşırı güven düzeylerinin sırasıyla hipotezleri kurulmuş ve aşağıdaki gibi değerlendirilmiştir. Hipotezleri test etmek amacıyla yine 'Bağımsız Örneklem TTesti ve Tek Yönlü Anova testi’ kullanılmış olup güven aralığı 0,05 alınmıştır.

Problem Cümlesi: Cinsiyete göre hisse senedi yatırımcılarının aşırı güven düzeyleri anlamlı farklılık göstermekte midir?

H0: Cinsiyete göre hisse senedi yatırımcılarının aşırı güven düzeyleri anlamlı farklılık göstermemektedir.

H1: Cinsiyete göre hisse senedi yatırımcılarının aşırı güven düzeyleri anlamlı farklılık göstermektedir.

Tablo 27: Yatırımcıların Aşırı Güven Düzeylerinin Cinsiyete Göre T-Testi Sonuçları

\begin{tabular}{|c|c|c|c|c|c|c|}
\hline Cinsiyet & N & Ortalama & SS & Sd & t & p \\
\hline Kadın & 88 & 2,4870 &, 774 & 329 & $-2,123$ &, 034 \\
\hline Erkek & 243 & 2,6743 &, 684 & & & \\
\hline
\end{tabular}

Tablo 27 incelendiğinde yatırımcıların cinsiyetleri ile aşırı güven arasında anlamlı bir farkl11ık olduğu (t $(329)=-2,123, p<0,05)$ tespit edilmiştir. Bu sonuçlara göre erkeklerin kadınlara göre daha fazla aşırı güvenli olduğunu söyleyebiliriz. Buna göre, erkek yatırımcıların kadın yatırımcılara oranla, kendi bilgilerine piyasadaki diğer bilgilerden daha fazla güvendiği, başarılarını kendilerine başarısızlıklarını kötü şansa yada bireylere atfettiği, belli bir sonuç elde edildikten sonra 'ben zaten biliyordum' iddiasını gösterdikleri, kendi görüşlerini destekleyen bilgiyi araştırma ama kendi fikirlerin aksini söyleyen bilgiyi reddetme eğiliminde oldukları tespit edilmiştir. Ayrıca, aşırı güvenli erkeklerin kadınlara oranla daha fazla işlem yapmakta oldukları da tespit edilmiştir. Barber ve Odeon'un (2001) yılında yayınlamış oldukları makalede de; erkek yatırımcıların $\% 45$ daha fazla kendilerine güvendikleri ve bu yüzden daha fazla işlem yaptıkları ortaya konmuştur.

\section{Problem Cümlesi: Medeni hale göre hisse senedi yatırımcılarının aşırı güven düzeyleri anlamlı farklıık göstermekte midir?}

H0: Medeni hale göre hisse senedi yatırımcılarının aşırı güven düzeyleri anlamlı farklılık göstermemektedir.

H1: Medeni hale göre hisse senedi yatırımcılarının aşırı güven düzeyleri anlamlı farklılık göstermektedir. 
Tablo 28: Yatırımcıların Aşırı Güven Düzeylerinin Medeni Duruma Göre T-Testi Sonuçları $(\mathrm{p}>0,05)$

\begin{tabular}{|c|c|c|c|c|c|c|}
\hline Medeni Hal & N & Ortalama & SS & Sd & t & p \\
\hline Evli & 243 & 2,6620 &, 700 & 329 & 1,592 &, 112 \\
\hline Bekar & 88 & 2,5211 &, 741 & & & \\
\hline
\end{tabular}

Tablo 28'de yatırımcıların aşırı güvenleri medeni hale göre farklılık göstermekte midir hipotezini değerlendirmek üzere yaptığımız t testi sonucunda $p>0,05 \quad(p=, 112)$ olduğundan anlamlı bir farklılık göstermemektedir. Bu nedenle H0 hipotezi kabul edilir.

Problem Cümlesi: Yaş Gruplarına göre hisse senedi yatırımcılarının aşırı güven düzeyleri arasında anlamlı bir farklılık var mıdır?

H0: Yaş Gruplarına göre hisse senedi yatırımcılarının aşırı güven düzeyleri arasında anlamlı bir farklılık yoktur.

H1: Yaş Gruplarına göre hisse senedi yatırımcılarının aşırı güven düzeyleri arasında anlamlı bir farklılık vardır.

Tablo 29: Yaş Gruplarının Betimsel İstatistiği

\begin{tabular}{|c|c|c|c|}
\hline Yaş Grubu & N & Ortalama & SS \\
\hline $18-20$ & 11 & 3,0000 &, 465 \\
\hline $21-30$ & 77 & 2,5417 &, 741 \\
\hline $31-40$ & 113 & 2,6144 &, 741 \\
\hline $41-50$ & 78 & 2,5952 &, 691 \\
\hline 51 -yukarıs1 & 52 & 2,7335 &, 668 \\
\hline
\end{tabular}

Tablo 29'da Hisse senedi yatırımcılarının yaş gruplarına göre aşırı güven düzeylerine ilişkin ortalama ve standart sapmaları verilmiştir. Bu tabloya göre, hisse senedi yatırımcılarının önyargılarının ortalaması 18-20 yaş grubu için 3,0000, 21-30 yaş için 2.5417, 31-40 yaş için 2,6144, 41-50 yaş için 2,5952 ve 50 yaş yukarısı için ise 2,7335 olarak bulunmuştur. En yüksek ortalamaya sahip iki yaş gurubu ise 18-20 ile 51 yaş yukarısı yaş grubu arasındadır. Bu ortalama değerler arasında manidar bir fark olup olmadığı tek yönlü varyans analizi ile sınanmış ve aşağıdaki bulgulara ulaşılmıştır.

Tablo 30: Yatırımcıların Aşırı Güven Düzeylerinin Yaş Gruplarına Göre Anova Sonuçları $(p>0,05)$

\begin{tabular}{|c|c|c|c|c|c|c|}
\hline & $\begin{array}{c}\text { Kareler } \\
\text { Toplamı }\end{array}$ & sd & $\begin{array}{c}\text { Kareler } \\
\text { Ortalaması }\end{array}$ & F & P & Anlamlı Fark \\
\hline Gruplar arası & 2,775 & 4 &, 694 & 1,371 &, 244 & - \\
\hline Gruplar içi & 164,884 & 326 &, 506 & & & \\
\hline Toplam & 98,475 & 330 & & & & \\
\hline
\end{tabular}

Tablo 30'da hisse senedi yatırımcılarının yaş gruplarına göre aşırı güven düzeylerinin arasında anlamlı bir farklılık olmadığı $(\mathrm{F}=1,371 ; \mathrm{p}>0,05)$ tespit edilmiştir. Dolayısıyla, H0 hipotezi kabul edilir. Küçüksille (2004) ve Saraç (2011)' ın yapmış olduğu konuyla ilgili çalışmaların aksine, yaş grupları ile aşırı güven arasında anlamlı bir ilişki olduğunu tespit edilmiştir. 
Problem Cümlesi: Eğitim durumlarına göre hisse senedi yatırımcılarının aşırı güven düzeyleri arasında anlamlı bir farklılık var mıdır?

H0: Eğitim durumlarına göre hisse senedi yatırımcılarının aşırı güven düzeyleri arasında anlamlı bir farklılık vardır.

H1: Eğitim durumlarına göre hisse senedi yatırımcılarının aşırı güven düzeyleri arasında anlamlı bir farkl1lık yoktur.

Tablo 31: Eğitim Durumların Betimsel İstatistiği

\begin{tabular}{|c|c|c|c|}
\hline Ĕ̈itim Durumu & N & Ortalama & SS \\
\hline ilkokul & 6 & 2,8571 &, 373 \\
\hline Ortaokul & 10 & 2,8429 &, 515 \\
\hline Lise & 52 & 2,7500 &, 764 \\
\hline Üniversite & 205 & 2,5456 &, 697 \\
\hline Yükseklisans/Doktora & 58 & 2,7291 &, 751 \\
\hline
\end{tabular}

Tablo 31'de Hisse senedi yatırımcılarının eğitim durumlarına göre aşırı güven düzeylerine ilişkin ortalama ve standart sapmaları verilmiştir. Bu tabloya göre, hisse senedi yatırımcılarının önyargılarının ortalaması ilkokul eğitimi için 2,8571, ortaokul eğitimi için 2.8429, lise eğitimi için 2,7500, üniversite eğitimi için 2.5456 ve yüksek lisans/doktora eğitimi için ise 2.7291 arasındadır. En yüksek ortalamaya sahip eğitim durumu ise ilkokul ve ortaokuldur. Bu ortalama değerler arasında manidar bir fark olup olmadığı tek yönlü varyans analizi ile sınanmış ve aşağıdaki bulgulara ulaşılmıştır.

Tablo 32: Yatırımcıların Aşırı Güven Düzeylerinin Eğitim Durumlarına Göre Anova Sonuçları (p>,05)

\begin{tabular}{|c|c|c|c|c|c|c|}
\hline & $\begin{array}{c}\text { Kareler } \\
\text { toplamı }\end{array}$ & sd & $\begin{array}{c}\text { Kareler } \\
\text { ortalaması }\end{array}$ & F & P & Anlamlı Fark \\
\hline Gruplar aras1 & 3,529 & 4 &, 882 & 1,753 &, 138 & - \\
\hline Gruplar içi & 164,130 & 326 &, 503 & & & \\
\hline Toplam & 98,475 & 330 & & & & \\
\hline
\end{tabular}

Tablo 32'de hisse senedi yatırımcılarının eğitim durumlarına göre aşırı düzeylerinin arasında anlamlı bir farklılık $(\mathrm{F}=1,753 ; \mathrm{p}>0,05)$ bulunmamaktadır. Dolayısıyla H0 hipotezi kabul edilir. Küçüksille (2004), Bellante ve Gren(2004), Brown ve Taylor (2007)'ın yapmış olduğu çalışmalardaki bulgularda bu çalışmanın bulgularını destekler niteliktedir.

Problem Cümlesi: Meslek gruplarına göre hisse senedi yatırımcılarının aşırı güven düzeyleri arasında anlamlı bir farklıık var mıdır?

H0: Meslek gruplarına göre hisse senedi yatırımcılarının aşırı güven düzeyleri arasında anlamlı bir farklılık yoktur.

H1: Meslek gruplarına göre hisse senedi yatırımcılarının aşırı güven düzeyleri arasında anlamlı bir farklılık vardır. 
Tablo 33: Meslek Grupların Betimsel İstatistiği

\begin{tabular}{|c|c|c|c|}
\hline Meslek & N & Ortalama & SS \\
\hline Öğrenci & 21 & 2,7687 &, 683 \\
\hline Ekonomist & 26 & 2,6429 &, 718 \\
\hline Akademisyen & 49 & 2,5364 &, 814 \\
\hline Memur & 75 & 2,5181 &, 646 \\
\hline İşçi & 35 & 2,9837 &, 581 \\
\hline Diğer & 125 & 2,5943 &, 724 \\
\hline
\end{tabular}

Tablo 33'de Hisse senedi yatırımcılarının meslek gruplarına göre aşırı güven düzeylerine ilişkin ortalama ve standart sapmaları verilmiştir. Bu tabloya göre, hisse senedi yatırımcılarının önyargılarının ortalaması öğrenciler için 2,7687, ekonomistler için 2,6429, akademisyenler için 2,5364, memurlar için 2,5181, işçiler için 2,9837 ve diğer meslek gurupları için ise 2,5943 arasındadır. En yüksek ortalamaya sahip iki meslek gurubu işçi ve öğrenci arasındadır. $\mathrm{Bu}$ ortalama değerler arasında manidar bir fark olup olmadığı tek yönlü varyans analizi ile sınanmış ve aşağıdaki bulgulara ulaşılmıştır.

Tablo 34: Yatırımcıların Aşırı Güven Düzeylerinin Meslek Gruplarına Göre Anova Sonuçları $(\mathrm{p}<0,05)$

\begin{tabular}{|c|c|c|c|c|c|c|}
\hline & Kareler toplamı & sd & $\begin{array}{c}\text { Kareler } \\
\text { ortalaması }\end{array}$ & F & P & Anlamlı Fark \\
\hline Gruplar arası & $6-304$ & 5 & 1,261 & 2,539 &, 028 & \\
\hline Gruplar içi & 161,355 & 325 &, 496 & & & \\
\hline Toplam & 167,659 & 330 & & & & \\
\hline
\end{tabular}

Tablo 34'de hisse senedi yatırımcılarının meslek gruplarına göre aşırı güven düzeylerinin arasında anlamlı bir farklılık olduğu $(\mathrm{F}=2,539 ; \mathrm{p}<0,05)$ tespit edilmiştir. $\mathrm{Bu}$ sonuçla; işçi ve öğrencilerin kendilerine diğer meslek gruplarından daha fazla aşırı güvendikleri ve bu yüzden riskleri düşük tahmine edip daha fazla risk alabilme eğilimine sahip oldukları görülmektedir. Çalışmanın bulguları, Küçüksille (2004) ve Saraç ve Kahyaoğlu (2011)'ın çalışmalarından elde ettikleri bulguları desteklemektedir.

Problem Cümlesi: Aylık Gelire göre hisse senedi yatırımcılarının aşırı güven düzeyleri arasında anlamı bir farklılık var mıdır?

H0: Aylık Gelire göre hisse senedi yatırımcılarının aşırı güven düzeyleri arasında anlamlı bir farklılık yoktur.

H1: Aylık Gelire göre hisse senedi yatırımcılarının aşırı güven düzeyleri arasında anlamlı bir farklılık vardır.

Tablo 35: Aylık Gelirlerin Betimsel İstatistiği

\begin{tabular}{|c|c|c|c|}
\hline Aylkk Gelir & N & Ortalama & SS \\
\hline $2.500-$ TL'den az & 141 & 2,6363 &, 662 \\
\hline $2501-5000$ & 136 & 2,6334 &, 709 \\
\hline $5001-7500$ & 33 & 2,3636 &, 933 \\
\hline 7.501-TL üzeri & 21 & 2,8980 &, 582 \\
\hline
\end{tabular}


Tablo 35’te hisse senedi yatırımlarının aylık gelirlerine göre aşırı güven düzeylerine ilişkin ortalama ve standart sapmaları verilmiştir. Bu tabloya göre, hisse senedi yatırımcılarının önyargılarının ortalaması 2.500-TL'den az aylık gelir 2,6363, 2.501-5.000-TL için 2,6334, 5.0017.500 için 2,3636 ve 7.501 ve üzeri için 2,8980 arasındadır. En yüksek ortalamaya sahip aylık gelir ise 7501 ve üzeridir. Bu ortalama değerler arasında manidar bir fark olup olmadığı tek yönlü varyans analizi ile sınanmış ve aşağıdaki bulgulara ulaşılmıştır.

Tablo 36: Yatırımcıların Aşırı Güven Düzeylerinin Aylık Gelire Göre Anova Sonuçları $(\mathrm{P}<, 05)$

\begin{tabular}{|c|c|c|c|c|c|c|}
\hline & $\begin{array}{c}\text { Kareler } \\
\text { toplamı }\end{array}$ & sd & $\begin{array}{c}\text { Kareler } \\
\text { ortalamas }\end{array}$ & $\mathbf{F}$ & P & Anlamlı Fark \\
\hline Gruplar arasi & 3,846 & 3 & 1,282 & 2,559 &, 05 & \\
\hline Gruplar içi & 163,813 & 327 &, 501 & & & \\
\hline Toplam & 167,659 & 330 & & & & \\
\hline
\end{tabular}

Tablo 36'da hisse senedi yatırımcılarının aylık gelirlerine göre aşırı güven düzeylerinin arasında anlamlı bir farklılık $(\mathrm{F}=2,559 ; \mathrm{p}<0,05)$ bulunmaktadır. Analiz sonuçlarına göre, farklı gelir gruplarına mensup bireysel yatırımcılar arasında yatırım yaparken kendilerine aşırı güven duyma açısından anlamlı bir fark olduğunu öne süren H1 hipotezi kabul edilmiştir. Ayrıca aylık geliri $7500 \mathrm{TL}$ den fazla olan yatırımcıların kendilerine daha fazla güven duymakta ve daha fazla risk alma eğilimden oldukları da tespit edilmiştir.

\section{SONUÇ}

$\mathrm{Bu}$ çalışma da yatırımcıların yatırım kararlarını verirken etkisi altında kaldıkları bir takım psikolojik eğilimlerin Batı Akdeniz Bölgesindeki (Antalya, Isparta ve Burdur) bireysel yatırımcılar için geçerli olup olmadığını araştırmak amaçlanmıştır. Bu amaçla yapılan analizlerde Antalya, Isparta ve Burdur'daki hisse senedi yatırımcılarına uygulanan 331 anketten elde edilen veriler kullanılmıştır.

Yapılan anket çalışmasında anket katılımcılarının demografik özellikleri incelenmiştir. Katılımcıların cinsiyetleri, medeni halleri, yaşları, eğitim durumları, meslekleri ve aylık gelirleri yapılan ankete alınan cevaplardan tespit edilmiştir. Verilen bu bilgiler doğrultusunda hisse senetlerine yatırım yapan yatırımcıların hisse senedi alıp satarken içinde bulunmuş oldukları bilişsel önyargıların dereceleri tespit edilmiştir.

Dolayısıyla bireysel yatırımcıların, hisse senetlerine yatırım yaparken göstermiş olduğu bilişsel önyargıların düzeylerini tespit etmek amacıyla yapılan bu araştırmada aşağıdaki sonuçlara ulaşılmışıtır;

$\checkmark$ Hisse senetlerine yapılan yatırımın erkekler tarafindan kadınlara oranla daha fazla tercih edildiği tespit edilmiştir.

$\checkmark$ Evli olanların hisse senetlerine daha fazla yatırım yaptıkları tespit edilmiştir. 
$\checkmark$ Hisse senetlerine en çok yatırım yapan yaş grubunun 31-40 arası, en az yatırım yapan yal grubunun ise 18-20 yaş arası olduğu gözlenmiştir.

$\checkmark$ Yatırım aracı olarak hisse senetlerini en fazla tercih eden bireysel yatırımcıların eğitim seviyesi yüksektir. Hisse senetlerine en çok üniversite mezunları yatırım yapmaktadır.

$\checkmark$ Hisse senetlerine en çok yatırım yapan meslek grubu memurlar ve diğer serbest meslek erbapları iken en az tercih eden meslek grubu ise öğrencilerdir.

$\checkmark$ Hisse senetlerine yatırım yapmayı en çok tercih eden bireysel yatırımcıların ortalama aylık gelirleri $2500 \mathrm{TL}$ den az ve 2500-5000 TL arasıdır.

$\checkmark$ Hisse senedine yatırım yapan yatıımcıların geneli 4 yılı aşkın tecrübeli yatırımcılar olduğu tespit edilmiştir.

$\checkmark$ Bireysel yatırımcıların portföylerini genellikle daha az şirkete yatırım yaparak sınırlı sayıda çeşitliliği benimsedikleri gözlenmiştir.

$\checkmark$ Hisse senedi yatırımcılarının hisse senetlerini ortalama 1 ay sürede elden çıkarmayı yani yatırımlarını kısa vadeli yapmayı tercih ettikleri tespit edilmiştir.

$\checkmark$ Yatırımcıların hisse senedi alım satımı yaparken genellikle aracı kurumların profesyonel yönlendirme hizmetlerinden bilgi almayı tercih ettikleri gözlenmiş̧tir.

$\checkmark$ Hisse senedi yatırımcılarının hisse senedi alım satımı yaparken genel olarak kendilerine güvendikleri ve kendilerini iyi bir yatırımcı olarak gördükleri tespit edilmiştir.

$\checkmark$ Hisselerin geçmiş başarıları ve performansları, yatırımcıların o hisse senedini alım satım yapmasındaki rolünün çok önemli bir düzeyde olduğu tespit edilmiştir.

$\checkmark$ Hisse senedi yatırımcılarının yaşları ve meslek grupları ile hisse senedi alım satım yaparken önyargı düzeyleri arasında bir ilişki olduğu tespit edilmiştir.

$\checkmark$ Hisse senedi yatırımcılarının cinsiyetleri ve meslek grupları ile hisse senedi alım satımı yaparken göstermiş olduğu aşırı güven arasında bir ilişki olduğu tespit edilmiştir.

Bulgulardan, bilişsel önyargıların bireyleri genelde sistematik olarak etkilediği ve geleneksel yaklaşımın öne sürdügünün aksine bireylerin önyargı ya da aşırı güven etkisiyle hatalarında düzeltme yapmadığı ya da yapamadığı çalışmada ortaya çıkmıştır. Özellikle yatırım kararları gibi belirsizlik durumlarında önyargıların artarak gerçek dışı kararlar alınmasına neden oluğu tespit edilmiştir.

Bireysel yatırımcıların bu önyargılara maruz kalmaması ya da önyargıların en aza indirgenmesi için geliştirilen yöntemlerden olan tecrübe ve uzmanlığın, öğrenme ile birleşmesiyle bu psikolojik önyargıların önemli ölçüde ortadan kalkacağı öngörülmektedir. Bununla birlikte, belirli ilkelerin izlenmesi ile uzmanların bilinçli yönlendirmeleri, bu önyargıları azaltmada önemli katkı sağlayacaktır. 


\section{KAYNAKLAR}

Barak, Osman (2008), "Davranışsal Finans: Teori ve Uygulama", Ankara, Gazi Kitabevi.

Barber, Brad M. -Terrance Odean. (2001), "Boys Will Be Boys: Gender, Overconfidence, And Common Stock Investment." Quarterly Journal Of Economics, pp.261-292.

Döm, Serpil (2003), "Yatırımcı Psikolojisi”, İstanbul, Değişim Yayınları.

Hanson, Jon D.- Douglas A. Kysar. (1999) "Taking Behavioralism Seriously: The Problem Of Market Manipulation." NYUL Rev. 74, p.630.

Otluoğlu, Emir (2009), "Davranışsal Finans Çerçevesinde Aşırı Güven Hipotezinin Test Edilmesi: İMKB'de Bir Uygulama“, İstanbul Üniversitesi, Sosyal Bilimler Fakültesi, İstanbul.

Pompain, Micheal (2006), " Behavioral Finance And Wealth Management”, New Jersey, Wiley.

Tversky, Amos -Daniel Kahneman, (1971): "Belief In The Law Of Small Numbers."Psychological Bulletin, 76.2, p. 105.

Tversky, Amos - Daniel Kahneman, (1973), "Availability: A Heuristic For Judging FrequencyProbability." Cognitive Psychology, 5.2, pp. 207-232.

Tversky, Amos-Daniel Kahneman, (1974):"Judgment Under Uncertainty: Heuristics And Biases." Science, 185.4157, pp. 1124-1131.

Tversky, Amos- Daniel Kahneman, (1979), "Prospect Theory: An Analysis Of Decision Under Risk." Econometrica: Journal Of The Econometric Society, Pp. 263-291.

Tversky, Amos -Daniel Kahneman. (1981), "The Framing Of Decisions And The Psychology Of Choice." Science 211.4481, pp.453-458.

Tversky, Amos - Daniel Kahneman, (1992) "Advances In Prospect Theory: Cumulative Representation Of Uncertainty." Journal Of Risk And Uncertainty, 5.4, pp 297-323.

Von Winterfeldt, Detlof- Ward Edwards. (1986): "Cognitive Illusions And Their Implications For The Law." Southern California Law Review, No. 59, pp.225-276. 